\title{
Diagnostics in ballast water management
}

\author{
Marcin Bielski ${ }^{1}$, Jacek Wachowicz ${ }^{2}$, Ryszard Bielski ${ }^{3, *}$, Arkadiusz Adamczyk ${ }^{4}$, \\ Hendra Jantanata ${ }^{5}$ \\ ${ }^{1}$ Shiprepair Yard Nauta SA, Newbuildings Division Gdańsk, Poland \\ ${ }^{2}$ UTP University of Science and Technology, Faculty of Management, Bydgoszcz, Poland \\ ${ }^{3}$ Gdańsk University of Technology, Faculty of Management and Economics, Gdańsk, Poland \\ ${ }^{4}$ Polish Naval Academy, Faculty of Mechanical and Electrical Engineering, Gdynia, Poland, \\ ${ }^{5}$ LGT Indonesia, Batam, Riau Island, Indonesia
}

\begin{abstract}
Diagnostics in ballast water management is the main remedy to protect against the threat of spreading invasive species that can be carried in ships' ballast tanks. This phenomenon is getting better known and understood. New and more effective methods of preventing threats related to this are being developed. Procedures are created to ensure environmental safety in the face of ever-increasing transport by sea. The article characterizes both the background of the problem, basic diagnostic medics used in ballast water management, as well as procedures and basic techniques used to ensure the safety of the natural environment..
\end{abstract}

\section{BACKROUND}

Nowadays most of cargo is being transported by sea. It may be not the fastest but for sur the cheapest solution. Vessels transport three to five billion tonnes of ballast water in one year period. Maritime scientist assumed that every given day, up to 10000 different marine species are released outside their natural habitats. We often consider which is the most economical way, but should that be the only one factor? We should not forget about the slogan "SAFETY FIRST". Hearing that we consider human and other living species safety, cargo and equipment safety. Awareness of growing risk that some species may be transported in ballast water to a brand new area, where due to lack of natural predators treating them they may dominate or even eliminate others. This threat, not only potential, has huge influence on marine environment.

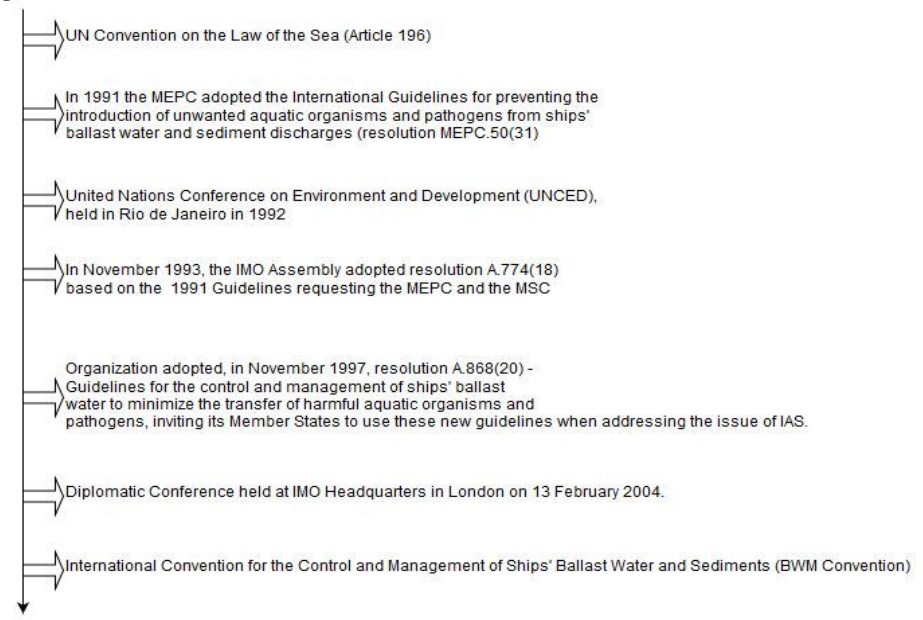

Fig. 1. Legislation evolution.

\footnotetext{
* Corresponding author: rysbiels@pg.edu.pl
} 
One of the legislation pointis Ballast Water Management Awareness. This subject is related to water transport form one to another region. It came together with steel-hulled vessels more than 100 years ago. Ballast operation is needed (due to its impact on vessel stabilisation) for safe travelling around seas and oceans. The first recognition of the problem of transportation of alien species is dated for 1903, when scientist discovered mass occurrence of the Asian phytoplankton algae Odontella in the North Sea.

MPEC - IMO Marine Environment Protection Committee is the Organization that put effort to establish rules that may prevent such cases of spreading unwanted organisms. The negotiation period can be counted in years. Global maritime community analyzed all pros and cos and decided that ballast water management is entering into force.

Diagram of legislation evolution is presented on Fig. 1.

Now we can find more than 25 regional authorities that announced their own requirements. As the main are treated: IMO and United States Coast Guard. However case study based on new technology implementation, should be divided into two groups: new buildings and retrofits. The thesis that it should be split into two case studies is related to practice installation conditioning. At the first quarter of the 2017 USCG revealed their final rule implementation schedule. The table 1 presents main dates and requirements

Table 1. USCG implementation schedule. [4]

\begin{tabular}{|l|l|l|l|}
\hline & $\begin{array}{l}\text { Total ballast } \\
\text { capacity }\end{array}$ & $\begin{array}{l}\text { Date of vessel } \\
\text { launching }\end{array}$ & Compliance date \\
\hline $\begin{array}{l}\text { New } \\
\text { buildings }\end{array}$ & All & $\begin{array}{l}\text { On or after 1 } \\
\text { Dec 2013 }\end{array}$ & On delivery \\
\hline Retrofits & $<1500 \mathrm{~m}^{3}$ & $\begin{array}{l}\text { Before 1 Dec } \\
2013\end{array}$ & $\begin{array}{l}\text { First scheduled dry-docking after 1 } \\
\text { Jan 2016 }\end{array}$ \\
& $\begin{array}{l}1500 \mathrm{~m}^{3}- \\
5000 \mathrm{~m}^{3}\end{array}$ & $\begin{array}{l}\text { First scheduled dry-docking 1 Jan } \\
2014\end{array}$ \\
\cline { 2 - 2 } & $>5000 \mathrm{~m}^{3}$ & $\begin{array}{l}\text { First scheduled dry-docking after 1 } \\
\text { Jan 2016 }\end{array}$ \\
\hline
\end{tabular}

Ship-owners must consider their operation area, because if they have clients in United States of America they have to install proper system for ballast water treatment. Having on mind strict restrictions USCG provides two additional compliance alternatives:

- Exclusive use of ballast water from a public water system in United States.

- Discharge of all ballast water into an onshore facility or another vessel, barge for treatment purposes.

\section{BALLAST WATER DIAGNOSTICS AND ITS ENFORCEMENT}

Ballast water management is governed by regulations which stipulate limits for: quantity of organisms as well as concentration of indicator microbes that are allowed to be discharged in ballast water. Units dedicated to ballast water treatment must show that they meet these limits not only during type approval, but also during whole product life cycle.

The maritime industry require standardization. BWM convention define international standards for ballast water treatment in Regulation D-2. According to diagnostics, which show measured levels different actions may be required. This may be divided into three consecutive levels, where different actions should be undertaken. This may be presented as on Fig. 2. 


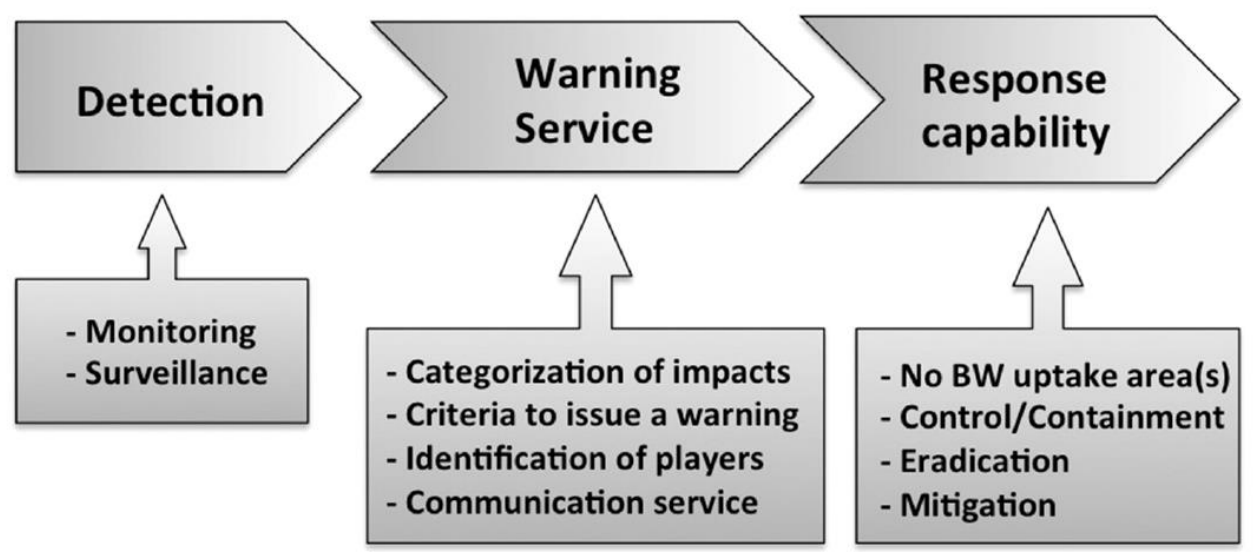

Fig. 1. Main components of an Early Warning System for Non-indigenous Species and Ballast Water Management. BW = Ballast Water. [6]

\section{DETECTION}

First step, in all cases requires measurement. This is very difficult issue in case of ballast water in ships, as they may only be probed - and outcomes may vary significantly due to ambient conditions, as presented on Fig. 6. Different probing techniqes may also be sensitive to various factors. Basic, simplest method is microscopic evaluation, which diagram is presented on Fig. 3. More advanced technique is HR-LOPC, which diagram is presented on Fig. 4 The FlowCAM technique is the first one that may execute tests in different classes of samples. Its diagram is presented on Fig. 5. A broad overview of existing specific methods can be found in [3].

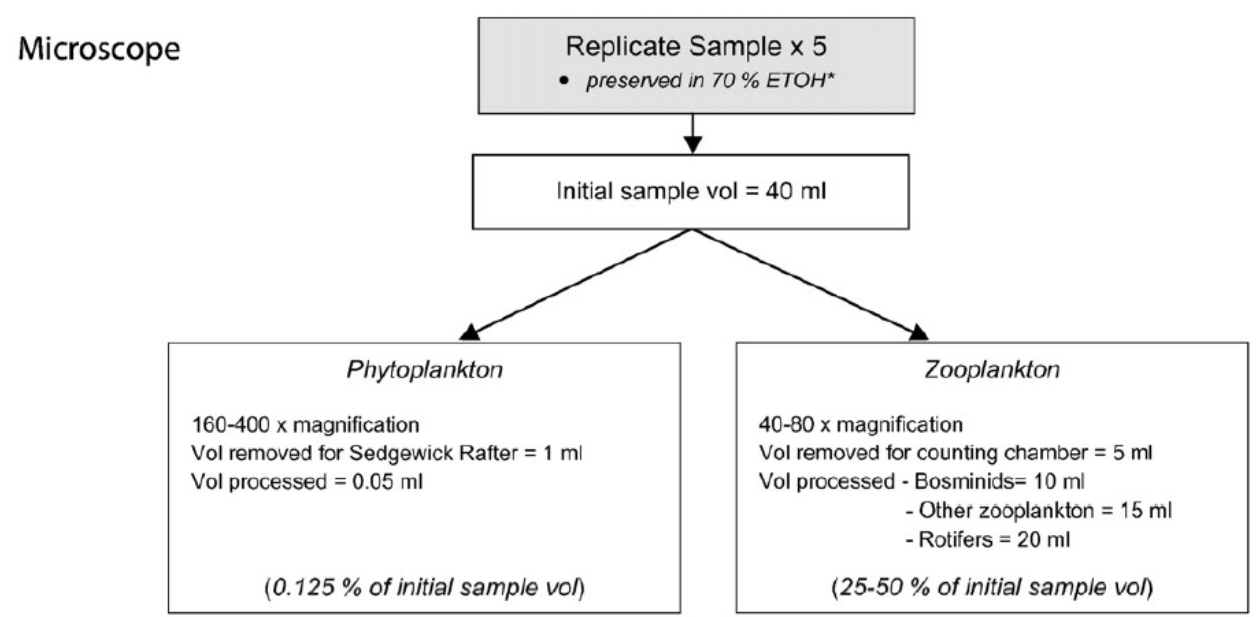

Fig. 3. Diagram of microscopic evaluation. [5] 
HR-LOPC

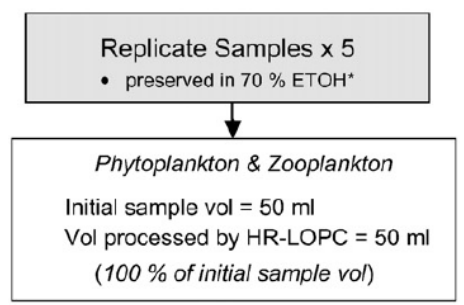

Fig. 4. Diagram of HR-LOPC evaluation. [5]

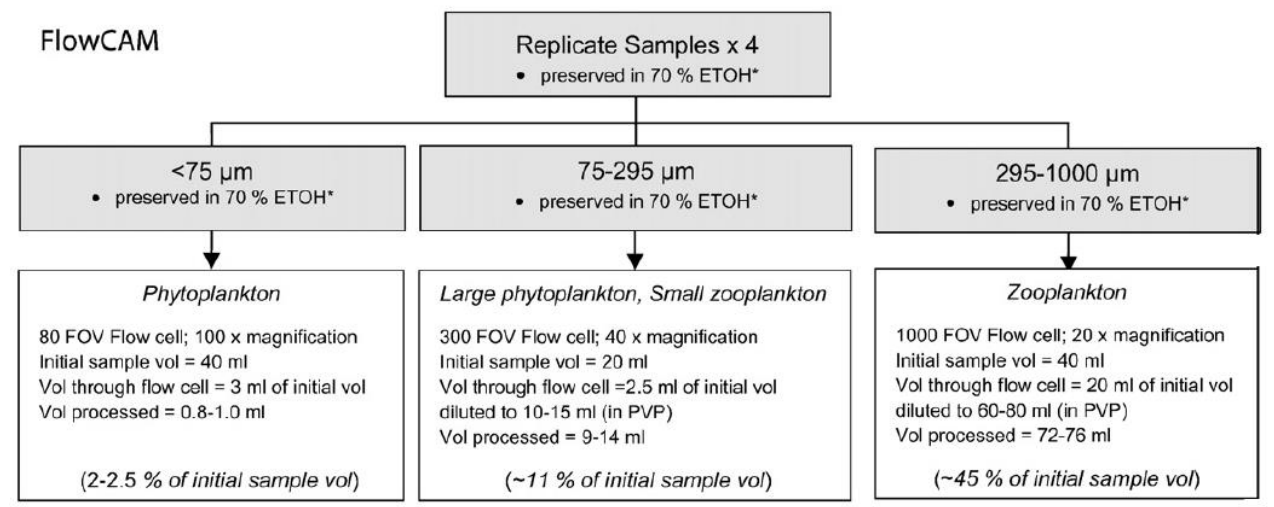

Fig. 5. Diagram of FlowCAM eevaluation. [5]

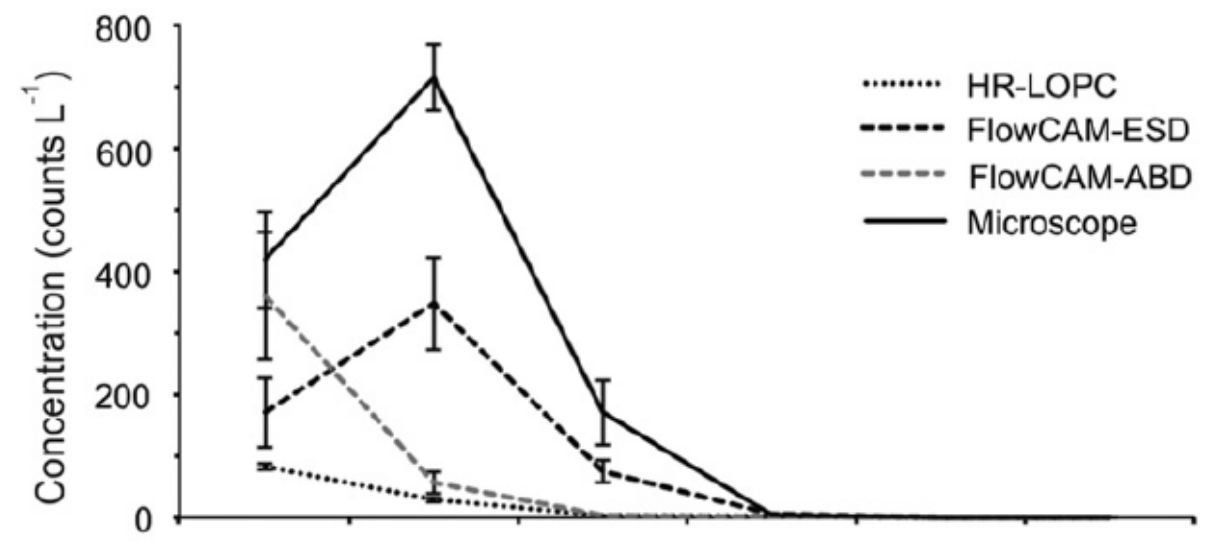

Fig. 6. Concentration plots for particles N $30 \mu \mathrm{m}$ measured by the HR-LOPC, FlowCAM (organism only) ESD and ABD measurements, and the microscope. [5]

Differences in method sensitivity resulted in spliting sampling methods into targeted ones (which are highly sensitive to specific spicies, but omit possible other ones, even if they had been very dangerous) and into community profilling (which are less accurate, but give responses to a far higher spectrum of potential threats). Their processes may be comared and presented as on Fig 7 
TARGETED DETECTION

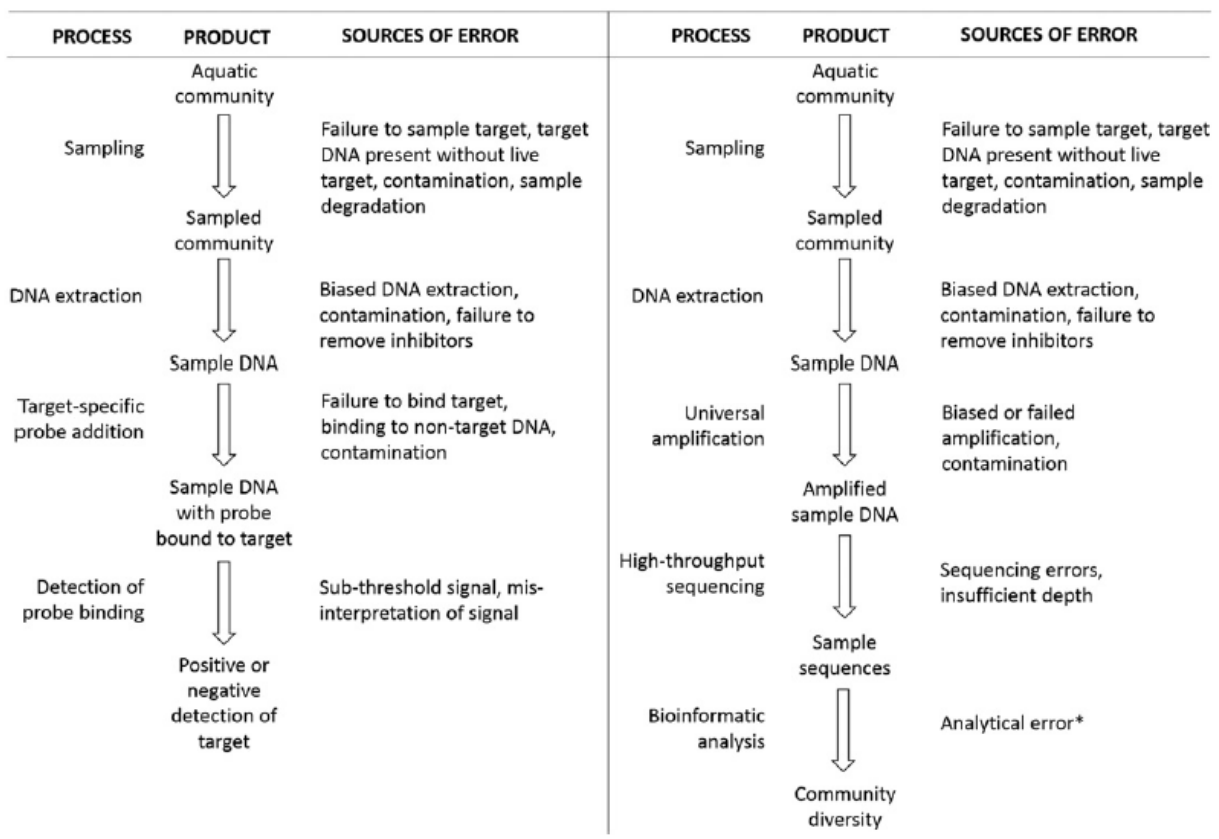

Fig. 7. Workflow for targeted probe-based detection (left) and HTS-based community profiling (right), including potential sources of error introduced at each process step. False positive and false negative errors can derive frommultiple steps in each process. ${ }^{*}$ Encompasses a broad range of error sources including, but not limited to, poor filtering of reads, failure to remove chimeras, and inaccuracies in taxonomic assignment.. [3]

Relatively new class of methods used in ballast water diagnostics are genetic methods. They offer brand new approach and possibilities, due to their extremely distinctive properties, as in comparison to traditional, morphological methods. The may be compared as on Fig. 8.

\begin{tabular}{|c|c|c|}
\hline Criterion & $\begin{array}{l}\text { Genetic } \\
\text { methods }\end{array}$ & $\begin{array}{l}\text { Traditional morphological } \\
\text { methods }\end{array}$ \\
\hline Sensitivity & HIGH & low \\
\hline Specificity & HIGH & low \\
\hline $\begin{array}{l}\text { Ability to identify sub-adult or partial } \\
\text { specimens }\end{array}$ & HIGH & low \\
\hline Ability to identify cryptic taxa & HIGH & low \\
\hline Quantification & low & $\mathrm{HIGH}$ \\
\hline Opportunity for passive surveillance & HIGH & low \\
\hline Affordability of up-front costs & low & $\mathrm{HIGH}$ \\
\hline Affordability per sample & $\mathrm{HIGH}^{*}$ & low \\
\hline Speed of analytical turnaround & HIGH & low \\
\hline False negative avoidance & HIGH & low \\
\hline False positive avoidance & low & $\mathrm{HIGH}$ \\
\hline
\end{tabular}

Fig. 8. Genetic vs. morphological methods. [3] 


\section{WARNING SERVICE AND RESPONSE CAPABILITY}

Results of ballast water testing testing may force necessity of further actions. They may have different directions - towards vessel, other vessels, or authorities. Simple graph of possible warning actions is presented on Fig. 9.

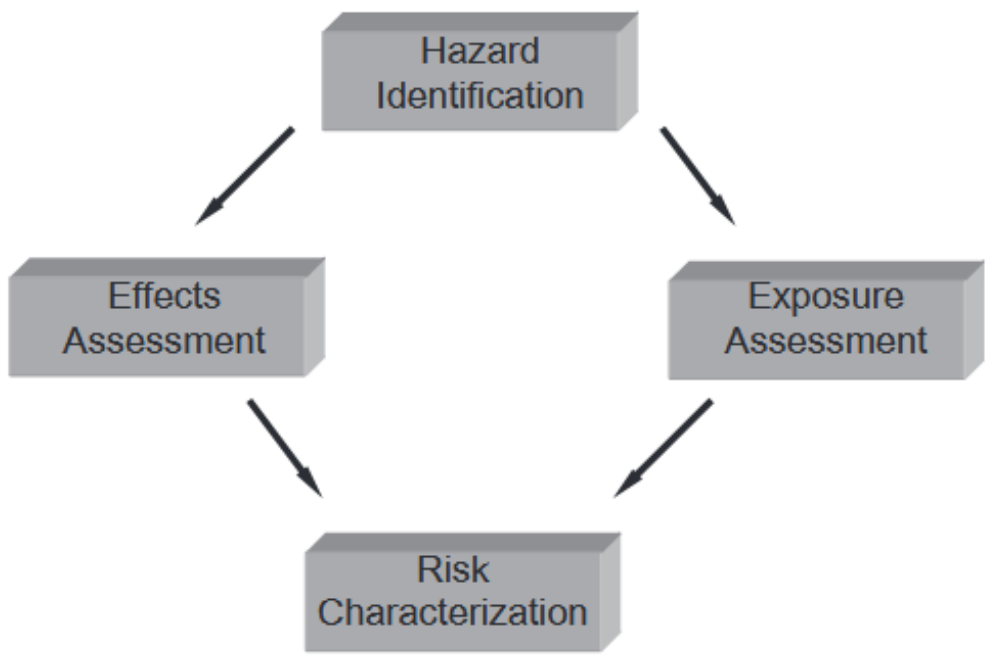

Fig. 9. Risk assessment approach. Four-step risk assessment approach. [1]

\begin{tabular}{ll}
\hline Group of organisms & Counts per volume \\
\hline$\geqslant 50 \mu \mathrm{m}$ & $<10$ per $\mathrm{m}^{3}$ \\
$\geqslant 10 \mu \mathrm{m}<50 \mu \mathrm{m}$ & $<10$ per mL \\
Vibrio cholerae & $<1$ cfu per $100 \mathrm{~mL}$ or \\
$(01$ and 0139$)$ & $<1$ cfu per $1 \mathrm{~g}$ (wet weight) \\
& zooplankton samples \\
Escherichia coli & $<250$ cfu per $100 \mathrm{~mL}$ \\
Intestinal Enterococci & $<100$ cfu per $100 \mathrm{~mL}$ \\
\hline
\end{tabular}

Fig. 10. The BWM Convention ballast water performance standard (Regulation D-2) for maximum limits of viable organisms per defined volume of discharged ballast water. [7]

Finding an excessive amount of chemicals or phyto- or zooplankton may require undertaking standard preventive actions to protect the local environment against the intrusion of alien species. The most widespread among them are presented in Fig. 10. Decision graph for additional actions may consist of many basic steps. It may be presented as on Fig. 11. 


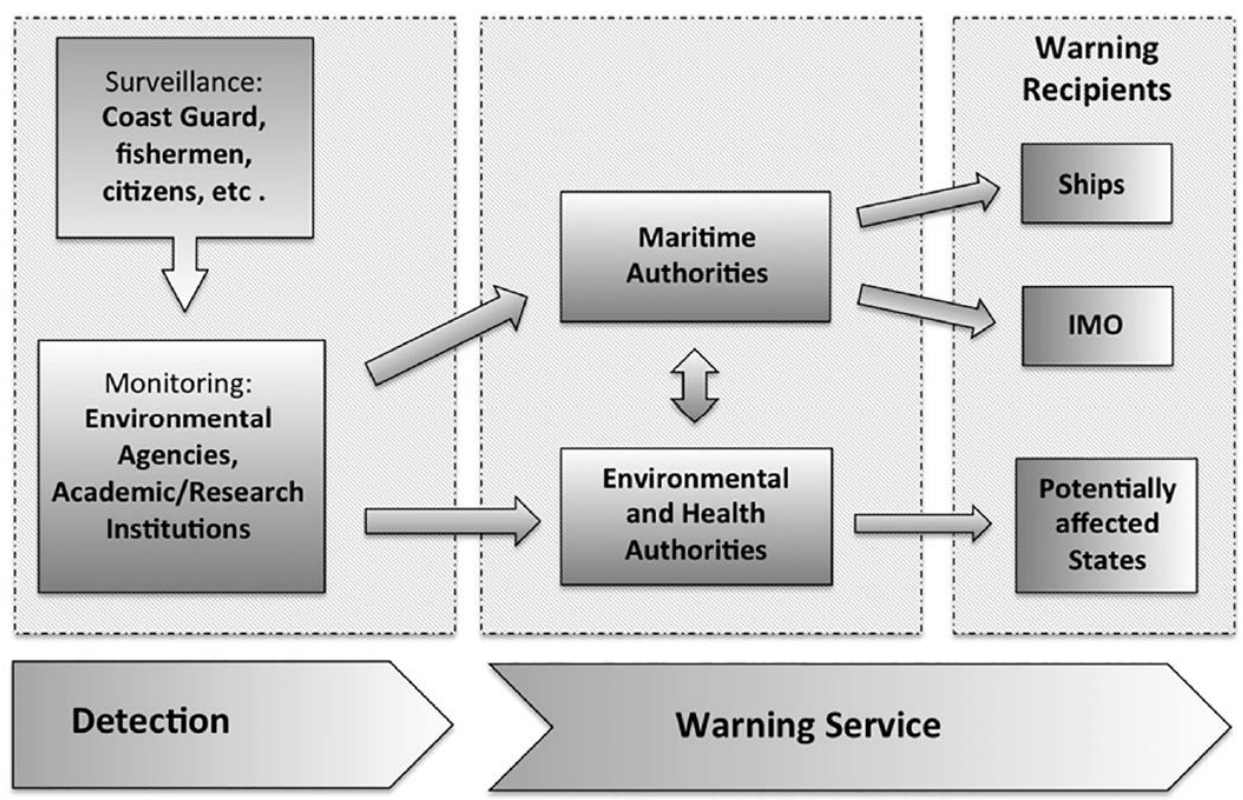

Fig. 11. Institutions, authorities and stakeholders involved in an Early Warning System for Nonindigenous Species and Ballast Water Management. [6]

Depending on hazard different actions may be required. They are illustrated on following Figures.

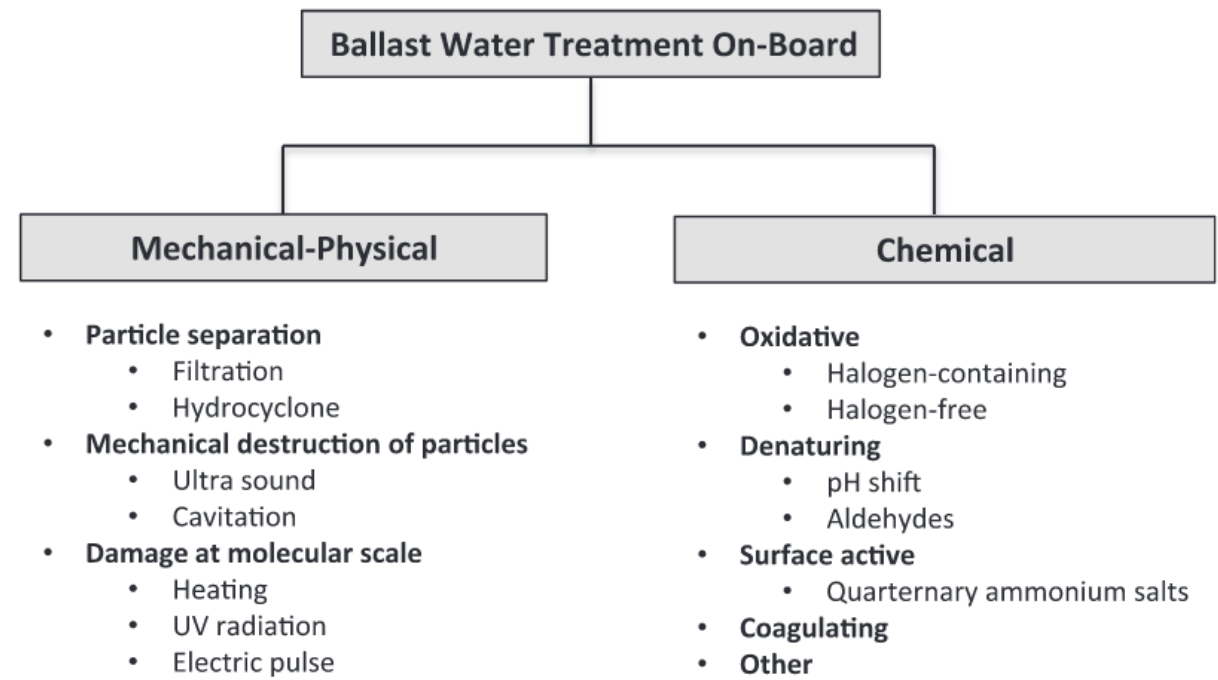

Fig. 12. Overview of ballast water treatment measures on board a ship. [7]

Most frequently used techniques reducing biohazards are shown on Fig. 13 


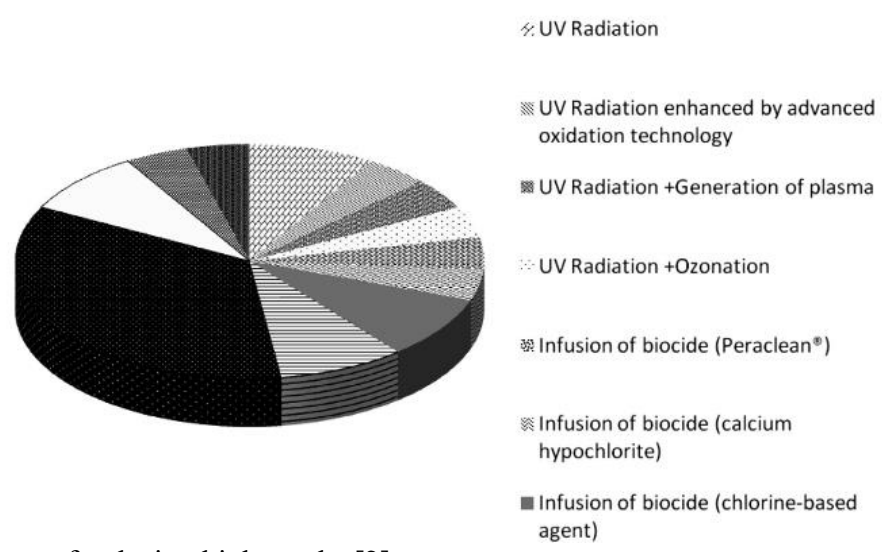

Fig. 13. Techniques of reducing biohazards. [2]

agent)

There is always a risk of injuries to human crew; some standard security procedures are shown on Fig. 14.

\begin{tabular}{|c|c|c|}
\hline Activity & Exposure & Quantification (IMO, 2012) \\
\hline $\begin{array}{l}\text { Crew } \\
\text { Handling of chemicals } \\
\text { Starting of BWMS } \\
\text { BW treatment } \\
\text { Ballasting/routine deck work } \\
\text { De-ballasting } \\
\text { Tank cleaning } \\
\text { Other maintenance work } \\
\text { Malfunctions, accidents }\end{array}$ & $\begin{array}{l}\text { Dermal/inhalation (leakages, spills) } \\
\text { Type-specific } \\
\text { Type-specific } \\
\text { Inhalation (BW tank exhaust) } \\
\text { Dermal/inhalation (spray drift) } \\
\text { Dermal (whole body)/inhalation } \\
\text { Type-specific } \\
\text { Inhalation/dermal }\end{array}$ & $\begin{array}{l}100 \mathrm{mg}(0.1 \mathrm{~mL}) / \text { container } \\
\text { Case by case } \\
\text { Case by case } \\
1 \mathrm{~h} \mathrm{~d}{ }^{1} \text { over } 6 \mathrm{mth}^{1} \\
\text { Not considered } \\
8 \mathrm{hd}^{1} \text { on } 5 \mathrm{~d} \mathrm{wk}{ }^{1}: 1 \mathrm{wk} \mathrm{y}^{1} \\
\text { Case by case } \\
\text { Not considered }\end{array}$ \\
\hline $\begin{array}{l}\text { General public } \\
\text { Swimming/recreational activities } \\
\text { Seafood consumption }\end{array}$ & $\begin{array}{l}\text { Inhalation/dermal/oral } \\
\text { Oral }\end{array}$ & $\begin{array}{l}5 \mathrm{hd}^{1} \text { on } 14 \mathrm{dy}^{1} \\
\sim 200 \mathrm{gd}^{1}\end{array}$ \\
\hline
\end{tabular}

Fig. 14. Scenarios and pathways for human exposure to chemicals from BWMS. [7]

In serious cases it may be necessery to inform other vessels. Such decision diagram is shown on Fig. 15.

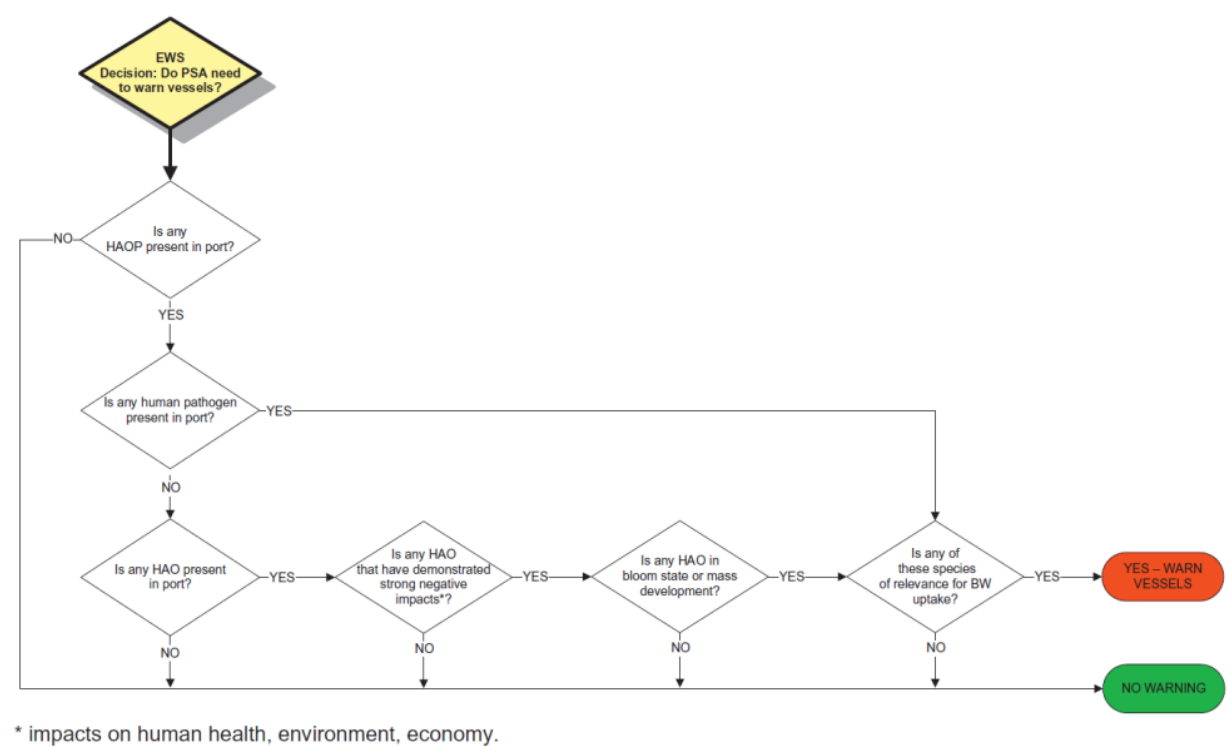

Fig. 15. Decision Support System model for an Early Warning System: warnings to vessels. EWS 
$=$ Early Warning System, PSA $=$ Port State Authority, HAOP $=$ Harmful Aquatic Organisms and Pathogens, HAO =Harmful Aquatic Organisms. [6]

\section{CONCLUSIONS}

Diagnostics in ballast water management is the main remedy to protect against the threat of spreading invasive species that can be carried in ships' ballast tanks. This phenomenon is getting better known and understood. However, it is still a problem widely known only to a small group of specialists. This article presents a comprehensive picture of the problem, characterizing the basic methods and procedures. It has a cognitive character, as well as allowing for a deeper look at the problems occurring as a result of the unintentional transport of living organisms in ballast water tanks.

\section{References}

1. S. Baner, B. Werschkun, T. Höfer, Assessing the risk of ballast water treatment to human health, Regulatory Toxicology and Pharmacology, Vol 62, Iss 3, April 2012 (2012)

2. J. Culin, B. Musta, Environmental risks associated with ballast water management systems that create disinfection by-products (DBPs), Ocean \& Coastal Management 105 (2015)

3. J. A. Darling, R. M. Frederick, Nucleic acids-based tools for ballast water surveillance, monitoring, and research, Journal of Sea Research, 133 (2018)

4. IMO/USCG D2 implementation scheme, DNV GL, https://www.dnvgl.de/maritime/ballast-water-management-imo-uscg.html accessed 2018-05-10

5. J. Kydd, H. Rajakaruna, E. Briski, S. Bailey, Examination of a high resolution laser optical plankton counter and FlowCAM for measuring plankton concentration and size, Journal of Sea Research, 133 (2018)

6. E. Magalettia, F. Garaventab, M. Davidc, L. Castriotad, R. Krause, G. M. Lunaf, C. Silvestria, C. Forteg, M. Bastianinih, M. Falautanod, T. Maggiod, G. Raka, S. Gollaschi; Developing and testing an Early Warning System for Non Indigenous Species and Ballast Water Management, Sea Research, 133 (2018)

7. B. Werschkuna, S. B. Oihane, C. Basurkob, M. David, F. Fuhrd, S. Gollasche, T. Grummtf, M. Haarich, A. N. Jhah, S Kacan, A. Kehrer, J. Lindersk, E. Mesbahi, D. Pughiuc, S. D. Richardsonn, B. Schwarz-Schulz, A. Shaho, N. Theobald, T. Höfer; Emerging risks from ballast water treatment: The run-up to the International Ballast Water Management Convention, Chemosphere, Vol. 112, October 2014 (2014) 